\title{
2 The Potato Late Blight Pathogen Phytophthora infestans and Other Pathogenic Oomycota
}

\author{
F. Govers ${ }^{1}$, A. Drenth ${ }^{2}$, and C.M.J. Pieterse ${ }^{3}$
}

\section{CONTENTS}

I. Introduction $\ldots \ldots \ldots \ldots \ldots \ldots \ldots \ldots \ldots \ldots$

II. Plant Pathogenic Oomycota ............ 18

III. Disease Cycle of Phytophthora infestans .... 18

A. Asexual Life Cycle ................. 18

B. Sexual Life Cycle ................. 19

C. Incompatible Interactions . . . . . . . 20

IV. Population Genetics of Phytophthora infestans...................... 21

A. Markers for Population Genetic Analysis ... 21

B. Central Mexico: the Center of Origin ...... 22

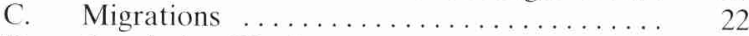

D. Population Displacement .............. 24

E. The Acquisition of Sexual Reproduction ... 25

V. Molecular Genetics of Plant Pathogenic

Oomycota ................................. 25

A. DNA Transformation ........................ 26

B. Structure of Oomycetous Genes .......... 26

VI. Elicitors Produced by Phytophthora Species . . . . . . . . . . . . . . . . . . . . . 27

VII. Pathogenicity of Phytophthora infestans .... 29

A. Differential Gene Expression During Pathogenesis ..................... 29

B. Differential Gene Expression During Starvation ..................... 33

VIII. Perspectives and Conclusions .......... 33 References .................. 33

\section{Introduction}

Potato late blight, caused by a member of the Oomycota, Phytophthora infestans (Mont.) De Bary, is one of the most important and devastating diseases of potato (Solanum tuberosum). The pathogen attacks both foliage and tubers, and spreads rapidly through host tissues, thereby

\footnotetext{
'Department of Phytopathology, Wageningen Agricultural University, Binnenhaven 9,6709 PD Wageningen, The Netherlands

CRC for Tropical Plant Pathology, The University of Queensland, Brisbane QLD 4072, Australia

Department of Plant Ecology and Evolutionary Biology, Section Phytopathology, Utrecht University, P.O. Box $800.84,3508$ TB Utrecht, The Netherlands
}

causing a destructive necrosis. $P$. infestans is a hemibiotrophic pathogen with a rather narrow range of hosts, all of them members of the Solanaceae. The crop plants, potato and tomato (Lycopersicon esculentum), are the economically most important hosts. The first late blight epidemic in Europe in 1845 had disastrous effects on potato production. $P$. infestans spread over Europe within 1 year (Bourke 1964) and was found in most potato-growing areas of the world soon thereafter. In Ireland the potato crop was destroyed in two successive years, leading to a famine. As a consequence, about one and a half million people died and another million emigrated, mainly to the United States (WoodhamSmith 1962). De Bary (1876) described the life cycle of the potato late blight pathogen and named it Phytophthora ("plant destroyer") infestans.

The extremely destructive nature of the disease and its worldwide distribution made potato late blight and the potato- $P$. infestans interaction favorite topics of research. Various aspects have been studied extensively (reviewed in Ingram and Williams 1991). In recent years, the new tools of molecular biology and molecular genetics have been applied to study the interaction in further detail.

In this chapter, we will first present some information on pathogenic Oomycota in general. This is followed by a description of the disease cycle of $P$. infestans and the mode of reproduction. We will then focus on the population genetics of the pathogen, and discuss the significance and consequences of the worldwide population displacement which resulted in the introduction of a new mating type in Europe around 1980. Subsequently, the current status of molecular genetic research on plant pathogenic Oomycota is summarized. The diverse nature of elicitors produced by various Phytophthora species is discussed and, finally, we focus on putative pathogenicity factors of $P$. infestans. 


\section{Plant Pathogenic Oomycota}

Phytophthora infestans belongs to the class Oomycetes, order Peronosporales, family Pythiaceae. Traditionally, the Oomycota were placed within the kingdom Fungi. However, structurally, biochemically, and genetically, they differ from all other taxa in the kingdom Fungi and are now placed in a separate monophyletic clade, the Stramenopila or chromista, together with the Hyphochytriomycota, Labyrinthulomycota, and several groups of algae with heterokont zoospores (Patterson and Sogin 1992; Hawksworth et al. 1995; Alexopoulos et al. 1996).

The most important plant-pathogenic Oomycota belong to the Pythiaceae and the Peronosporaceae, two families in the order Peronosporales. The best-known genera of the Pythiaceae are Phytophthora and Pythium. The genus Pythium includes some notorious soil-borne plant pathogens which cause seedling damping-off, root rot, and soft rot in a large variety of plants. All Phytophthora species, about 60 in total, cause a wide range of diseases on a large variety of plants. Some cause root or stem rots, others cause rots of buds or fruits and some cause foliar blight. Some species have a wide range of host plants, whereas others are restricted to one or a few hosts. P. cinnamomi, for example, is pathogenic on almost 1000 different species of trees and shrubs. In contrast, $P$. sojae (syn. P. megasperma f. sp. glycinea) can infect only one host, i.e., soybean.

The family Peronosporaceae comprises the very destructive organisms commonly known as the downy mildew pathogens. From a historical point of view, the best known is Plasmopara viticola, the causal agent of downy mildew on grapes, which destroyed vineyards throughout Europe in the 1870s-1880s. In terms of genetics the best known is Bremia lactucae. Here, the main focus has been the inheritance of avirulence genes that interact in a gene-for-gene manner with major resistance genes in the host, lettuce (Crute 1992). Unfortunately, the biotrophic nature of Bremia lactucae and the inability to transform this organism hamper further progress of these studies. A downy mildew pathogen which is receiving a lot of attention lately is Peronospora parasitica. It attacks crucifers, among which is Arabidopsis thaliana, the model plant for genetic and molecular studies. Recently, it has been demonstrated that $P$. parasitica and $A$. thaliana have a gene-forgene relationship (Holub et al. 1994) and genetic analysis of this interaction has already resulted in the identification of genes from A. thaliana involved in race-specific resistance. It is likely that the isolation of a gene that confers resistance against an oomycetous pathogen will be accomplished in the near future. Another oomycetous fungus pathogenic on A. thaliana is Albugo candida (Holub et al. 1993). Albugo is the only genus in the third family of the Peronosporales, the Albuginaceae. The genus comprises the white rust pathogens which are economically of minor importance.

\section{Disease Cycle of Phytophthora infestans}

\section{A. Asexual Life Cycle}

In spring, when potato tubers are planted, diseased sprouts may arise from tubers which are infested with mycelium of $P$. infestans (Fig. 1). Under favorable conditions, sporangiophores emerge from the stomata and release numerous airborne sporangia causing a rapid spread of the disease. At temperatures above $12-15^{\circ} \mathrm{C}$ sporangia may germinate directly. Below $12^{\circ} \mathrm{C}$, sporangia may differentiate into numerous motile zoospores which germinate after encystment. On leaf surfaces and stems, germinated sporangia and cysts form germ tubes with appressoria from which penetration hyphae arise. From the sporangia and cysts that germinate on the leaf surface only a small proportion actually penetrates the epidermal cells. Characteristically, the anticlinal walls of epidermal cells are penetrated by the penetration hyphae and often the cells next to stomatal guard cells are the target sites for penetration. Hyphal structures are formed in the epidermal cell from which the mycelium grows, initially intercellularly, while intracellular haustoria are formed in the mesophyll cell layer (Coffey and Gees 1991; Freytag et al. 1994).

The first macroscopic sign of lesion development is the appearance of water-soaked areas. While the pathogen grows, the center of the spreading lesion becomes necrotic. Sporulation is visible at the advancing edges of the developing lesion where sporangiophores emerge predominantly from the stomata. The expanding necrosis eventually leads to complete destruction of foliage and, consequently, in reduction of tuber yields. 


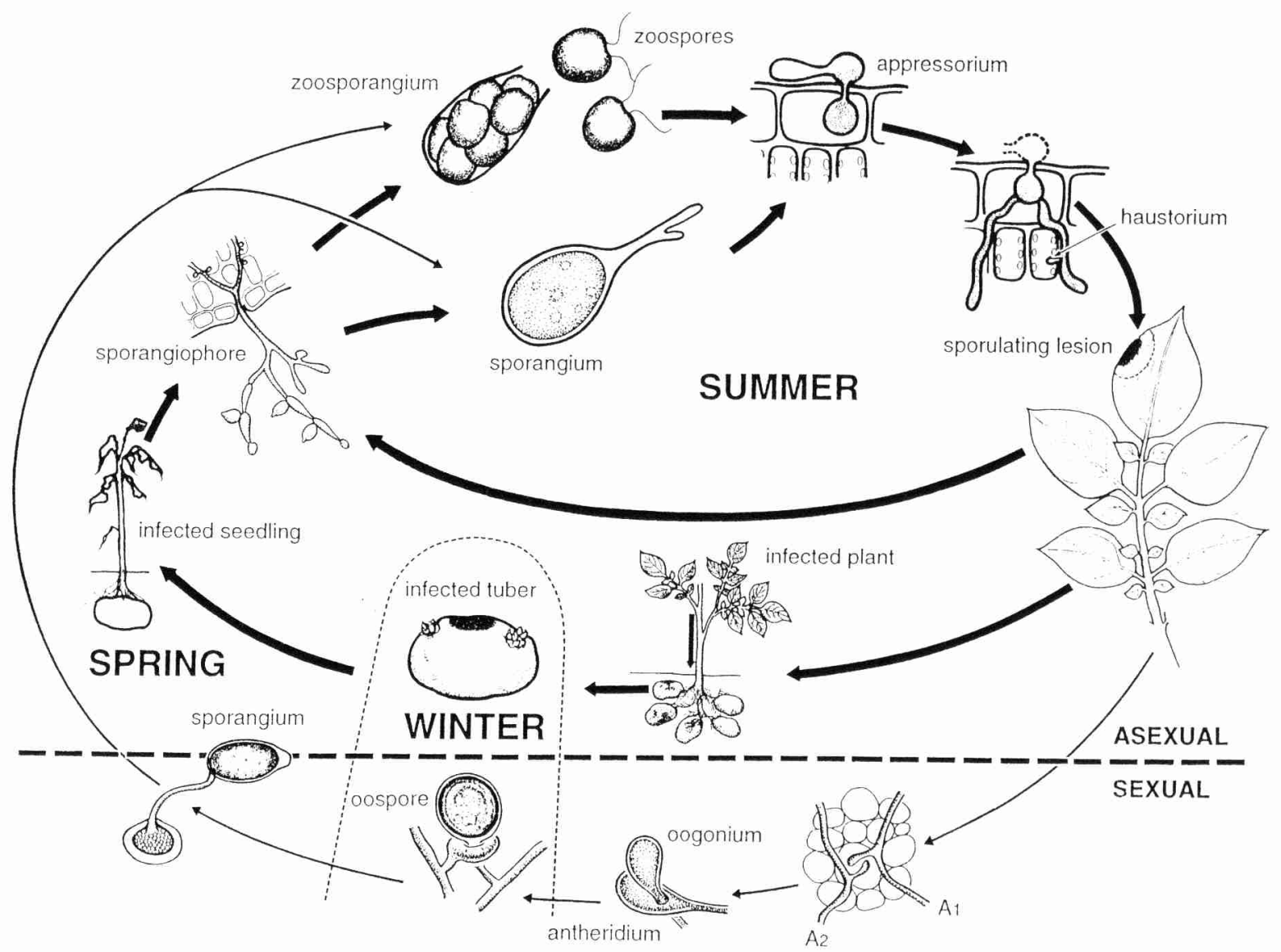

Fig. 1. Disease cycle of potato late blight and life cycle of Phytophthora infestans

Under favorable conditions, such a rapidly expanding lesion, carrying numerous sporangiophores with abundant sporangia, is formed within 4 to 5 days after infection. Many asexual generations may be produced in one growing season, which explains the enormous capacity for spread and epidemic development of the disease. The airborne sporangia can spread over distances up to several hundred kilometers. In wet weather conditions, sporangia or zoospores are washed down from the leaves and carried into the soil. Here the spores germinate and the germ tubes may penetrate the tubers at lenticels, wounds, and eyes, or at sites where the surface is not completely suberized. Most of the blighted tubers will rot in the soil or during storage. However, a few will survive the winter and they are the source for new infections when they sprout in the following season.

\section{B. Sexual Life Cycle}

$P$. infestans is a heterothallic species with two known mating types, A1 and A2. Both mating types are required for sexual reproduction, and in nature, oospores are produced only when hyphae of opposite mating type grow in each other's vicinity in infected host tissue. When the A1 and A2 hyphae make contact, antheridia and oogonia are formed. The oogonium grows through the antheridium in an amphigynous configuration in which the antheridium surrounds the oogonial stalk (Fig. 1). There is no exchange of cytoplasm between antheridium and oogonium. The oogonium expands rapidly due to the flow of cytoplasm through the oogonial stalk from its own thallus. Meiosis occurs in the multinucleate gametangium (Shaw 1983). All nuclei in the oogonium, except one, migrate to the periphery, where they disinte- 
grate. A fertilization tube grows from the antheridium through the oogonial wall to deposit an antheridial nucleus in the oogonium. The nuclei fuse and while the oospore matures a thick oospore wall develops. When blighted potato plants containing oospores remain in the field, they decompose and, as a result, oospores are liberated. In general, oospores of Oomycota are highly persistent structures. For some Phytophythora species it has been shown that oospores can survive in soil for several years. When the surviving oospores germinate, they can infect tubers and stolons of newly planted potatoes, as well as stems and leaves which come into contact with the soil (Schöber and Turkensteen 1992; Drenth et al. 1995).

Since only A1 mating type isolates were present in most potato-growing areas of the world, the sexual life cycle was not very important for the disease cycle of $P$. infestans. With the population displacement in the late 1970s, A1 and A2 mating types were introduced in Europe (see Sect. IV.C; Fry et al. 1993), and there is strong evidence that here sexual reproduction is now integrated in the disease cycle (Drenth et al. 1994, 1995; Sujkowski et al. 1994).

\section{Incompatible Interactions}

In nature, many different races of $P$. infestans occur. They vary in their capacity to infect different host cultivars. When a virulent race attacks a susceptible host cultivar, a compatible interaction develops and the host plant is readily destroyed, as described above. However, when the host cultivar has an appropriate major resistance $(\mathrm{R})$ gene which confers race-specific resistance, the pathogen may be recognized by the host in an early stage and the interaction turns out to be incompatible. Supposedly, race-specific resistance in the $P$. infestans-potato interaction is based on a gene-for-gene relationship (Black et al. 1953). For several pathosystems a gene-for-gene relationship has been demonstrated (Thompson and Burdon 1992; Chap. 1, this Vol.). It is suggested that in such a relationship, the products of avirulence genes of the pathogen, the so-called race-specific elicitors, interact with the products of the matching major resistance genes of the host. This interaction results in triggering of a hyper- sensitive response (HR) which is recognized by rapid cell death of invaded host cells and a limited number of cells surrounding the infection site (Tomiyama 1983). In this way, the biotrophic pathogen is arrested in growth and remains confined to the focus of infection. Little is known about the genetic and molecular basis of virulence/avirulence in $P$. infestans. Spielman et al. $(1989,1990)$ found that avirulence towards the potato resistance gene R3 and the tomato resistance gene $\mathrm{Ph} 1$ is dominant whereas avirulence towards R2 and R4 is recessive. Doke et al. (1993) have indications that certain $P$. infestans races produce race-specific suppressors which are thought to suppress the activity of general elicitors, thereby making an interaction compatible.

Comparison of the behavior of different races of $P$. infestans on various potato cultivars has demonstrated that at the stage of spore germination and penetration, virulent and avirulent races behave similarly (Coffey and Gees 1991; Freytag et al. 1994). However, in an incompatible interaction, further growth of hyphal structures that succeeded in penetrating the epidermis is effectively inhibited within the epidermis or the mesophyll. Further spread of the lesion is prevented by the hypersensitive response which is observed in all invaded host cells. Even in compatible interactions, mesophyll cells may react with hypersensitive cell death. In the potato cultivar Datura, which has the R1 resistance gene, it has been shown that infection with a compatible virulent race leads to varying degrees of hypersensitive responses. At some sites, only a few mesophyll cells respond hypersensitively whereas at other sites many cells do. The final phenotypic outcome of compatible or incompatible interactions, which are qualitatively clearly distinguished as either complete destruction or largely undisturbed survival of the plant, is very likely to be the consequence of comparatively small quantitative effects: a slightly large number of reacting cells appears to be sufficient to prevent spread and sporulation of $P$. infestans in the incompatible interaction (Freytag et al. 1994). Whether this small quantitative difference is related to differences in the amount of race-specific elicitor or suppressor produced at a certain site in the infected tissues in unknown. As long as the nature of race-specific elicitors or suppressors is unclear, this remains an open question. 


\section{Population Genetics of Phytophthora infestans}

Central Mexico is considered to be the center of origin of $P$. infestans. In the mid-19th century, the first appearance of potato late blight outside Mexico was reported. The disease was found in the USA and Europe, and since then has appeared wherever potatoes are grown. Of the two mating types that are required for sexual reproduction of $P$. infestans, only one, A1, was known before the early 1950s. At that time the second mating type, A2, was discovered in isolates collected in the Toluca Valley in Central Mexico, although they were then known from nowhere else in the world. This changed in the early 1980s when A2 mating type isolates appeared in Europe. This was the first indication that the populations were changing dramatically and it stimulated plant pathologists all over the world to analyze local populations. Currently, A2 mating type isolates are present all over northern Europe, in Asia, in several African countries, in South America, and in North America (summarized in Drenth et al. 1993b). Thus, the changes in the populations appear to have occurred on a worldwide scale, and most certainly result from migration.

\section{A. Markers for Population Genetic Analyses}

Characterizations of $P$. infestans populations have relied on a series of markers which have contributed significantly to our understanding of the population genetics of the pathogen. The markers available for $P$. infestans can be classified in three categories: biologically significant markers, cytoplasmic markers, and neutral markers. They are briefly summarized below. From the available markers, neurtral polymorphic DNA markers appear to be the most powerful for population genetic analyses.

Biologically significant markers include mating type, fungicide resistance, and virulence. The mating type of an isolate is readily determined by scoring oospore formation upon cocultivation with A1 and A2 tester isolates. Fungicide resistance is easily detectable in mycelium grown in vitro on an appropriate medium. Virulence can be determined by assaying compatibility and incompatibility in a differential set of potato lines with the 11 known resistance genes (R-genes). Before the 1980 s, virulence was the only marker available to assess variation in $P$. infestans populations. A problem for using virulence as an unambiguous marker is the lack of a universal differential set of potato lines and a universal virulence assessment method. This seriously limits the interpretation of data in the numerous papers concerning variation for virulence. Moreover, the stability of virulence phenotypes has been the subject of much debate. Virulence and fungicide resistance are traits on which an enormous selection pressure can be exerted through the use of resistant potato cultivars or the application of fungicides. Strong selection on particular characteristics can dramatically alter the frequency of certain genotypes in the fungal population, thus requiring careful interpretation of data.

Cytoplasmic markers are mitochondrial DNA (mt-DNA) and double-stranded RNA (ds-RNA). Their main characteristic is the extrachromosomal inheritance leading to intact transmission from parent to progeny. The origin and the function of ds-RNA, which has been found in only a limited number of isolates, is unknown (Newhouse et al. 1992). Cytoplasmic markers are very useful to determine the global movement of plant pathogens, to infer phylogenetic relationships among different Phytophthora species, and to follow anastomosis and cytoplasmic inheritance. However, they are not suited for unambiguous identification of different isolates. The number of polymorphisms for mt-DNA and ds-RNA in P. infestans is rather limited. Because they are transmitted without recombination from parent to progeny they cannot reflect the true diversity in a population.

Neutral markers are called neutral because they are not related to biologically important characteristics. Neutral markers can be subdivided in allozyme markers and polymorphic DNA markers. More than 50 different enzymes were tested for their usefulness as allozyme marker for $P$. infestans, but only two appeared to show polymorphism (Tooley et al. 1985; Spielman et al. 1990). A number of different techniques are currently being used to detect DNA polymorphisms. Hybridization of digested genomic DNA with moderately repetitive DNA probes or short oligonucleotide repeats allows simultaneous detection of restriction fragment length polymorphism (RFLP) at numerous loci in the genome. A prerequisite for this so-called DNA fingerprinting is 


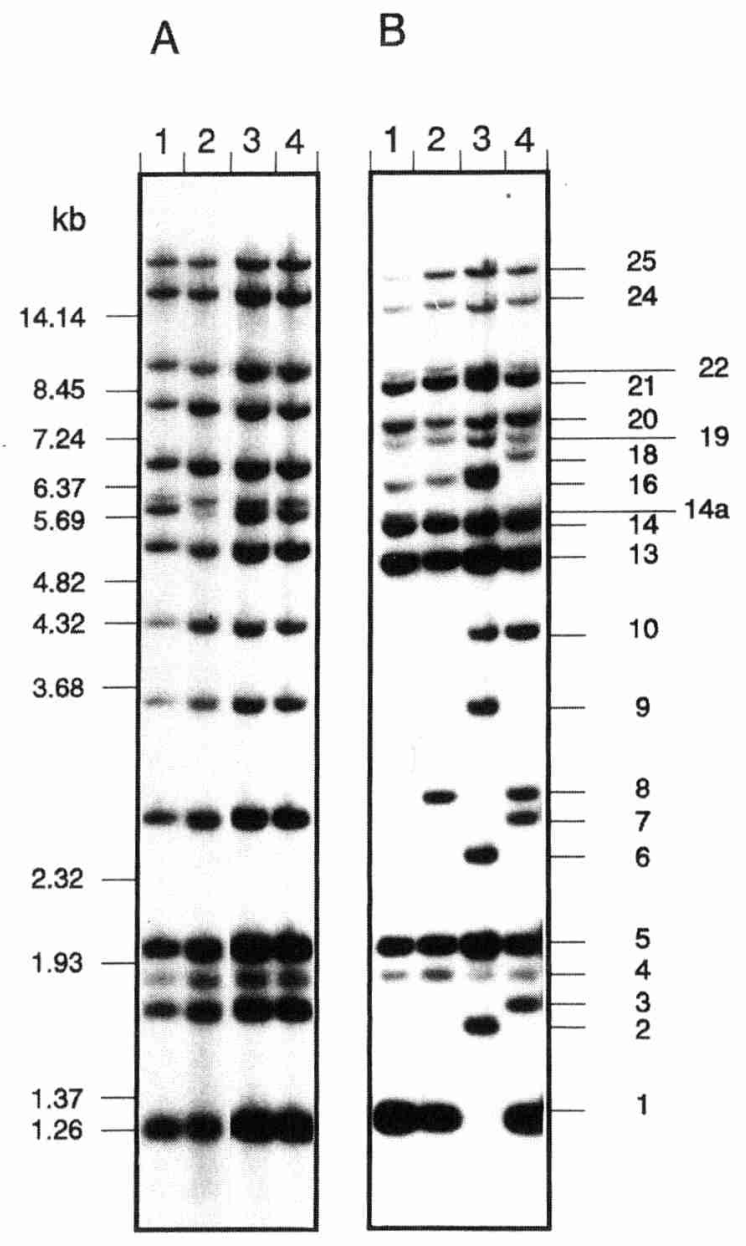

Fig. 2A,B. RG-57 DNA fingerprinting patterns from "old" and "new" $P$. infestans isolates. The "old" isolates shown in A were collected in 1966 (1), 1968 (2), 1974 (3), and 1978 (4). The "new" isolates shown in B were collected in 1986 (1) and in 1988 (2,3, and 4). Size markers in kilobases (kb) are indicated on the left. RG-57 fragments numbers are indicated on the right. (Drenth et al. 1994)

that the probe hybridizes to loci which are dispersed all over the genome and which are inherited independently. A moderately repetitive DNA probe that has been used routinely for DNA fingerprinting of $P$. infestans is RG-57, a random genomic DNA fragment of $P$. infestans. It hybridizes to more than 25 nonallelic polymorphic fragments of EcoRI-digested $P$. infestans DNA (Fig. 2). The banding pattern is stable through asexual reproduction and each hybridizing fragment appears to represent a unique genetic locus. Probe RG-57 allows virtually unambiguous identification of different isolates (Goodwin et al. 1992a).

\section{B. Central Mexico: the Center of Origin}

It has been known for a long time that many of the wild tuber-bearing Solanum species native to central Mexico have resistance to $P$. infestans. Several resistance genes that have been introduced by breeding into domesticated potatoes (Solanum tuberosum subsp. tuberosum) are derived from wild Mexican Solanum species. The natural occurrence of many different resistant Solanum species along with a diverse pathogen population suggested that the Solanum-P. infestans pathosystem evolved in central Mexico (Niederhauser and Mills 1953). The observation made in the early 1950 s that the two mating types of $P$. infestans, A1 and A2, both occur in Mexico was a strong indication that, indeed, the pathogen has its origin in the central highlands of Mexico. In Mexico, the frequency of A1 and A2 mating type isolates is equal and the isolates are extremely diverse for both virulence factors and neutral markers. Many different and complex races have been found there. and all known allozyme alleles and RG-57 hybridizing fragments are represented in Mexican isolates (Goodwin et al. 1992b). Genotypic characterization of isolates collected during an epidemic in Toluca Valley in 1988 revealed an extremely large number of unique genotypes, and this diversity occurred despite the predominance of asexual reproduction during the epidemic. The large number of distinct genotypes strongly indicates that sexual reproduction occurs frequently in $P$. infestans populations in central Mexico (Fry et al. 1993).

\section{Migrations}

The first reported escape of $P$. infestans from Mexico occurred in 1843 , when a new potato disease appeared in the northeastern part of the United States. Two years later the pathogen had reached Europe, and from there it has probably been distributed to the rest of the world via the international trade in seed potatoes. Since there is no evidence for new migrations from Mexico during the interval between 1840 and the mid 1970s, it is now generally assumed that for more than 130 years only a single genotype dominated the $P$. infestans populations outside Mexico. This historical clonal lineage, which was recently designated US-1 (Goodwin et al. 1994), has the A1 mating type. 
In 1984, Hohl and Iselin reported the discovery of isolates with the A2 mating type among their P. infestans cultures which had been collected in Switzerland in 1981. By the mid 1980s, many other culture collections and field isolates had been screened for mating type and it turned out that the A2 mating type had been present in several European countries since the late 1970s. With the appearance of A2 mating type isolates, the diversity for virulence factors increased significantly (Drenth et al. 1994). The virulence diversity in European isolates was found to be as high as in isolates from central Mexico (Mills and Niederhauser 1953; Goodwin et al. 1992b) and this strongly suggested that the appearance of new isolates was the result of a new introduction. Evidence for this was gathered from the genotypic characterization of large numbers of $P$. infestans isolates (Spielman et al. 1991; Drenth et al. 1994). These studies revealed that in Europe not only new A2 mating type isolates were introduced, but also new A1 mating type isolates, and that this new population has now completely displaced the original historical clonal lineage, the US-1 type isolate. An extensive comparative study of isolates collected in the Netherlands before and after 1980 (Drenth et al. 1994) showed that before 1980 all old Dutch isolates had the US-1 genotype (Figs. 2, $3 b)$. Among 33 isolates only 4 different races, consisting of combinations of virulence factors, 1, 3, 4, and 10 , were identified (Fig. 3a). Thus, there was scarcely any diversity in the population, and the limited diversity found for virulence matched the R-genes present in commonly used potato cultivars. Among isolates collected after 1980, the A2 mating type appeared along with the A1 mating type, and new allozyme alleles and RG-57 genotypes were found. In 179 isolates collected between 1980 and 1991, 134 different RG-57 genotypes occurred, of which 121 were found

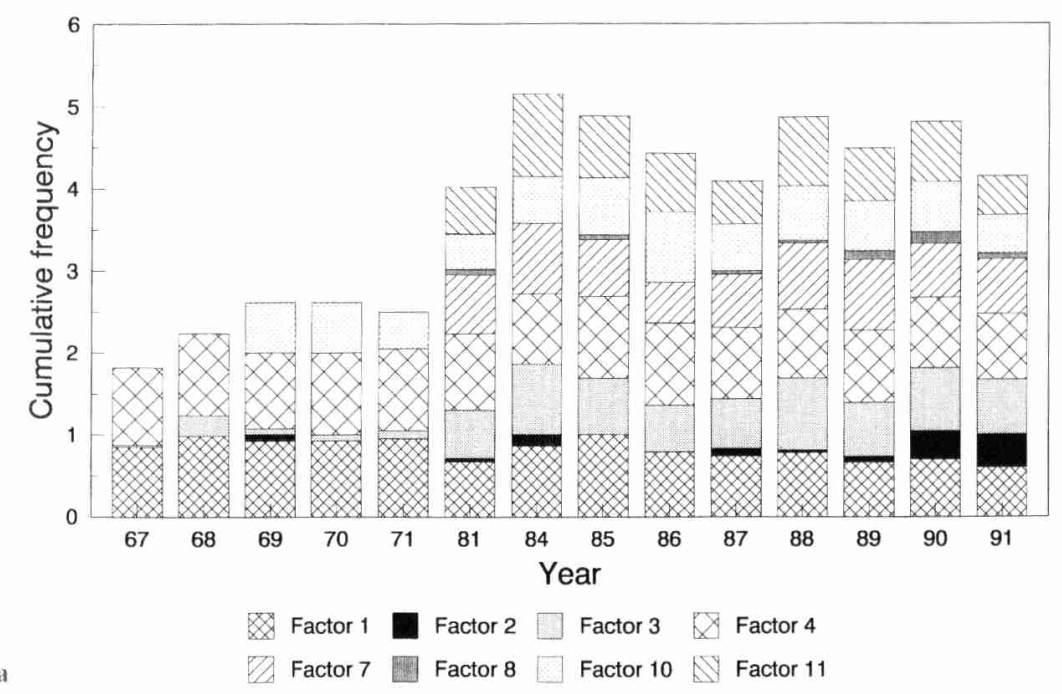

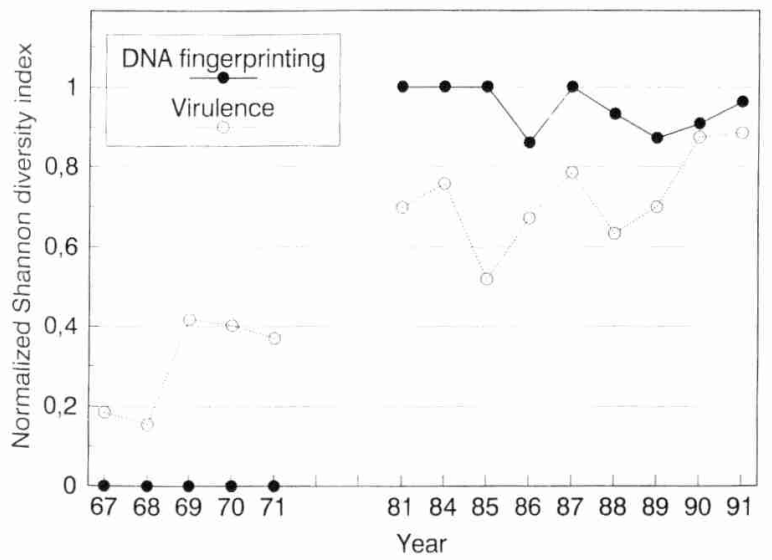

Fig. 3. a Yearly cumulative frequency of virulence factors in 148 "old" (1967-1971) and 253 "new" (1981-1991) $P$. infestans isolates. For the number of isolates and races per year see Table 1 in Drenth et al. (1994). Virulence factors 5 and 6 are not included in the bars. They were not found in the "old" isolates and only at very low frequency in the "new" isolates (0.011 and 0.023 , respectively). (Drenth et al. 1994) b Genetic diversity as calculated by the normalized Shannon diversity index for virulence and RG-57 DNA fingerprinting for $P$. infestans populations collected between 1967 and 1991. (Drenth et al. 1994) 
only once (Fig. 3b). Diversity for virulence and complexity of races increased tremendously (Fig. 3a). Among 253 isolates, 73 different races were identified. These races contained many unnecessary virulence alleles (e.g., 5, 6, 7, 8, and 11) for which there are no corresponding resistance genes in the array of potato cultivars grown in The Netherlands.

During the 1980s, the new population that first appeared in western Europe around 1980 and completely displaced the old population, migrated rapidly eastward and is now present in Asia and Africa. More recently, in the late 1980s, the first A2 mating type isolates were found in the United States and Canada. Now A2 mating type isolates are widely distributed over northern America. Genotypic characterization of isolates collected in various regions indicated that there was a massive immigration of new genotypes directly from northwestern Mexico and not via Europe (Goodwin et al. 1994). The appearance of several unique genotypes in British Columbia (Canada) in 1992 and 1993 is the first evidence for the probable occurrence of sexual reproduction of $P$. infestans in America north of Mexico (S.B. Goodwin and W.E. Fry, pers. comm.).

\section{Population Displacement}

The observation that the virulence diversity and genetic diversity in the new European isolates is as high as in the Mexican isolates indicates that again, as in $1845, P$. infestans escaped from Mexico and was able to establish in Europe. In 1976, a severe drought reduced the potato harvest in Europe and in the spring of 1977 vast quantities of potatoes were transported from Mexico to Europe. Possibly this potato import was accompanied by new $P$. infestans isolates, either in the form of mycelium in potato tubers or as oospores attached to potato tubers. In 1980 and 1981, genetically different A1 and A2 mating type isolates were found in a number of countries nearly simultaneously whereas the old US-1 genotype started to disappear rapidly. In The Netherlands, no US1 genotype has been found since 1980. That the discovery of these new isolates took at least 3 years probably can be explained by the widespread use of fungicides, which may have efficiently restricted the spread of the pathogen.

In 1845, a single year sufficed for $P$. infestans to spread over vast parts of Europe (Bourke
1964); at that time, however, no control measures were available and potato fields were heavily blighted, producing immense quantities of spores. The fact that the population displacement in The Netherlands occurred relatively fast, within 1 or 2 years, indicates that the current $P$. infestans isolates possess a higher fitness than the isolates which were present before 1980 . We have found that sexual progeny produced by in vitro pairing of old A1 and new A2 isolates have a very low fitness and are not very pathogenic (A. Drenth, unpubl.). This reduced fitness may be explained by the buildup of a huge mutational load in the old A1 population. As the A1 mating type isolates present before the introduction of the new population are all US-1 types, they originate from the initial introduction of $P$. infestans to Europe in 1845. They were thus restricted to asexual reproduction for about 130 years. With an average of 20 generations per year and a mutation rate of $11.2 \times$ $10^{-6}$ per gene per generation (Schlager and Dickie 1971), the probability of a mutation over 2600 generations will be 0.029 per gene. The unfavorable effects of many mutations will be masked as long as there are undamaged copies of the genes available. This is especially true for the old population. which was predominantly tetraploid. However. the mutational load in the old A1 mating type isolates may have reduced their suitability for sexual reproduction to a great extent, and it might be responsible for the poor pathogenicity of sexual progeny produced by crossing old A1 and new A2 mating type isolates.

Another catalyst for a rapid population displacement by new $P$. infestans isolates might have been the introduction of metalaxyl in 1979. Very soon after its introduction, in 1980 , resistance to this fungicide was found among $P$. infestans isolates (Davidse et al. 1981). Resistance to metalaxyl may have been present in the newly introduced isolates from Mexico, or alternatively, with the advent of sexually reproducing populations, the new isolates might have been able to acquire the resistance more rapidly. The large-scale application of metalaxyl in 1979 and in 1980 provided an intense selection pressure for resistant isolates, leading to a tremendous increase in their frequency in the population (Davidse et al. 1981). No metalaxyl-resistant isolates were found in the old, tetraploid $P$. infestans isolates collected before 1980. In the new $P$. infestans population, resistance to metalaxyl was found in various A1 and A2 mating type isolates with different genetic 
backgrounds (Drenth et al. 1993a), suggesting many independent mutations leading to metalaxyl resistance and/or the inheritance of resistance through sexual reproduction.

\section{E. The Acquisition of Sexual Reproduction}

The observation that the population displacement in 1980 with new A1 and A2 mating type isolates of $P$. infestans coincided with a change from little, if any, diversity in the old population to a very high level of diversity in the new population strongly suggested that the $P$. infestans population has acquired the ability to reproduce sexually which, in turn, is the driving force behind the high level of genetic diversity. To support this suggestion, we searched for the occurrence of oospores in the field and investigated whether the Dutch climate allows survival of oospores in soil between growing seasons. In 1992 we found oospores in blighted potato and tomato plants in the field. In addition, we used well-characterized parental isolates for survival studies. Oospores were allowed to develop in leaves, and the infested leaves were mixed with soil and exposed to natural weather conditions during the winter of 1992-1993. After 8 months, the soil still contained infectious material. DNA fingerprinting confirmed that infections on leaves, which contacted the soil containing the oospores, indeed resulted from oospores and were not caused by mycelium or vegetative spores from any of the parental isolates. Moreover, we found that soil samples taken in June 1993 from potato fields, which had been inoculated the year before, were still infectious. DNA fingerprinting showed that these infections were caused by progeny from the two parental isolates used to inoculate the field plots in 1992, demonstrating that oospores can overwinter in soil (Drenth et al. 1995).

Whether or not sexual reproduction has advantages over asexual reproduction has been a point of much debate (Charlesworth 1989). In the case of $P$. infestans the advantages are obvious. Firstly, $P$. infestans is a hemibiotrophic pathogen whose asexual spores, in contrast to oospores, cannot survive for long periods outside the host plant. When oospores are part of the life cycle, $P$. infestans can survive in soil between growing seasons, thereby increasing its ability to colonize new host plants and to propagate. Secondly, sexual reproduction results in a wider variety of genotypes and this, in turn, leads to an increased ability to respond to changes in the environment and to selection pressure. This is illustrated by the speed at which the new $P$. infestans population developed resistance to the fungicide metalaxyl (Davidse et al. 1981). In some countries, where the new sexually propagating populations have not yet appeared, metalaxyl is still used successfully to control late blight. Thirdly, the increased diversity of virulence patterns and the appearance of new virulence factors, through sexual recombination, enables the pathogen to avoid recognition by any specific resistance gene or combinations of resistance genes in the potato population.

Established disease management strategies are based on the biological characteristics of the old asexual $P$. infestans population. With an asexually propagating population, mycelium retained in seed potatoes or in potato refuse piles produces infectious spores, and this results in typical focal epidemics. Hence, control measures involve disease-free seed potatoes and removal of potato refuse piles. With the acquisition of sexual reproduction resulting in the presence of oospores in soil, late blight epidemics can start anywhere in the field as soon as potatoes have emerged. Thus, a general epidemic, originating from oospores, may appear despite sufficient removal of infected tubers containing mycelium. To anticipate epidemic development, detailed studies on oospore production, survival, germination, and infectivity are needed to determine the parameters of late blight epidemics caused by the new $P$. infestans population. These parameters are likely to be different from those in epidemics caused by old isolates, and we expect that the current disease management strategies will have to be adjusted accordingly.

\section{Molecular Genetics of Plant-Pathogenic Oomycota}

In the late 1980s, molecular genetic approaches were introduced in the research on $P$. infestans and other plant-pathogenic Oomycota. From various Phytophthora and Pythium species and from Bremia lactucae, random DNA fragments or ribosomal genes have been cloned and they are used for identification of strains, for population analyses and for genome mapping. Currently, PCRbased techniques (e.g., RAPDs) are frequently employed for the same purposes. To elucidate the nature of factors that determine pathogenicity or 
elicitors which induce resistance reactions in the host plant, putative pathogenicity genes and genes encoding elicitors have been cloned and characterized (see below). In addition, some oomycetous genes encoding housekeeping enzymes and structural proteins have been isolated. After numerous unsuccessful attempts to transform representative Oomycota, stable DNA transformation of several Phytophthora species has now been accomplished. The observation that DNA transformation of $P$. infestans is successful only when expression of marker genes or antibiotic resistance genes is regulated by oomycete regulatory sequences suggests that oomycetous gene promoters have special features which are required for high level expression.

\section{A. DNA Transformation}

For functional analysis of genes and manipulation of gene products, DNA transformation is a crucial tool. Initial attempts to transform $P$. infestans were reported by Kinghorn et al. (1991), who used various transformation vectors of which several had been proven to be successful in a diverse array of filamentous fungi. However, no stable transformants were generated. Judelson and Michelmore (1991) assayed transient expression of the GUS reporter gene in $P$. infestans regulated by promoters of oomycetous genes. By using optimized transformation conditions deduced from the transient expression assays and vectors containing chimeric genes consisting of transcriptional regulatory sequences from the Bremia lactucae ham 34 or hsp 70 genes and the coding region of the bacterial HPG or NPTII gene conferring resistance to hygromycin B or G-418, respectively, Judelson et al. (1991) were the first to obtain stable transformants of $P$. infestans. In the same year, transformation of $P$. parasitica and $P$. capsici with a stably maintained self-replicating plasmid was reported (Bailey et al. 1991). In these two Phytophthora species, as well as in P. citricola and P. cinnamomi, the promoter of the $h s p 70$ gene of the heterobasidiomycete Ustilago maydis seems to be able to drive the expression of the hygromycin resistance gene (Bailey et al. 1993) whereas in P. infestans no activity of the $U$. maydis $h s p 70$ promoter, when fused to GUS, was detectable (Judelson et al. 1992).

The most direct way to study the function of a gene and its gene product is by disrupting the gene and examining the effect on biological properties which are thought to be governed by that particular gene. In several plant-pathogenic fungi, e.g., Cladosporium fulvum (Marmeisse et al. 1993; Chap. 1, this Vol.), Fusarium solani f. sp. pisi (Stahl and Schäfer 1992), and Magnaporthe grisea (Sweigard et al. 1992; Chap. 3, this Vol.), the functions of avirulence genes or putative pathogenicity genes have been studied by gene disruption or gene replacement. However, this approach requires a highly efficient DNA transformation system and although in recent years the transformation efficiency of $P$. infestans has improved, it is still relatively low when compared to efficiencies obtained with other organisms. Moreover, Phytophthora species are diploid organisms; some isolates are even tetraploid. Therefore, inactivation of a target gene requires simultaneous disruption of at least two alleles. Sequential disruption of multiple alleles by integrative transformation has been achieved in the diploid fungus Candida albicans with the so-called ura-blaster protocol (Alani et al. 1987). However, to apply this protocol to Phytophthora, new marker genes and stable auxotrophic mutants must be developed. Disruption of the two alleles can also be obtained by sexual crosses. In the case of a homothallic species this is a straightforward procedure but with heterothallic species like $P$. infestans, forced self-fertilization is necessary.

An alternative approach to study gene function involves reducing or blocking the synthesis of gene products by means of anti-sense RNA. The anti-sense technique has been tested in $P$. infestans using sense and anti-sense GUS constructs, and was shown to be effective in inhibiting the accumulation of GUS up to $98 \%$ (Judelson et al. 1993).

\section{B. Structure of Oomycetous Genes}

In the past few years, the number of cloned oomycotan genes has been increasing steadily. The picture emerging from gene structure analyses is that most of these genes lack introns. So far, only two oomycetous genes are known which may have introns: the $P$. infestans niaA gene (Pieterse et al. 1995) and the trpl gene of $P$. parasitica encoding an enzyme of the tryptophan biosynthetic pathway (Karlovsky and Prell 1991). Transformation experiments have demonstrated that gene promoters isolated from higher fungi, from plants, or from mammalian and plant viruses (SV40 and 
Table 1. Conserved sequence motif in promoters of oomycetous genes. Alignment of the DNA regions surrounding the conserved sequence motif GCTCATTYYNCA(A/T)TTT which is present within the first $100 \mathrm{nt}$ upstream of the ATG start codon of ten oomycetous genes. (After Pieterse et al. 1994b)

\begin{tabular}{|c|c|c|c|c|c|}
\hline Gene & DNA & sequence surroun & in the conserved GCTCAT & $\mathrm{YYNCA}(\mathrm{A} / \mathrm{T}$ & TT motif \\
\hline P. infestans ipi $B^{\mathrm{b}}$ & -94 & GCCGTCCAGA & $\begin{array}{l}\text { GCTCATTTCCCATTCT } \\
\star \star \star * \star * \star * * * * * * * * *\end{array}$ & ССТCCCT & -62 \\
\hline P. infestans ipiOI & -40 & TCCGCTAAGA & $\begin{array}{l}\text { GCTCATTTGTGAATTC } \\
\star \star \star \star \star \star * * * * \star \star * *\end{array}$ & АTTTCTT & -8 \\
\hline P. infestans ubi3 $R^{\mathrm{d}}$ & -66 & CGCCTCCTTT & 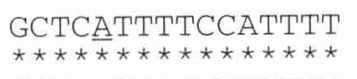 & GAGCGGA & -34 \\
\hline$P$. infestans cal $A^{\mathrm{e}}$ & -62 & TTTTGGATGG & $\begin{array}{l}\text { GATCATTGTTGGATTT } \\
\star \star \star \star \star \star \star * \star \\
\star \star \star \star * \star\end{array}$ & CCCTCGA & -30 \\
\hline P. infestans act $A^{\mathrm{fg}}$ & -84 & TCССТСTTTG & $\begin{array}{l}\text { GCTCATTTCCC / TTTT } \\
\star * \star \star * * * * * * \star * \star * * *\end{array}$ & CTTCCAG & -53 \\
\hline P. infestans act $B^{1}$ & -60 & GTGTCAAAGT & $\begin{array}{l}\text { TCTCATTCTGCATTTT } \\
\star * \star \star * * * * * \star * \star * * *\end{array}$ & GTCTCGA & -28 \\
\hline P. parasitica parA $I^{\mathrm{h}}$ & -69 & GCCTCCAACT & $\begin{array}{l}\text { GC / CATTGTGCAATTT } \\
\star * \star * * * * * * \star * \star * * *\end{array}$ & GСTCTCA & -38 \\
\hline P. sojae actin & -71 & GGACCTTGCT & $\frac{\text { CGTCATTCCGCAATTT }}{\star \star \star \star * \star * \star * * * \star * \star * *}$ & GCTGCCA & -39 \\
\hline P. sojae 42-kDa elicitor ${ }^{\mathrm{i}}$ & -71 & & $\frac{\text { ccattCTCCAATCT }}{\star \star * * \star * * * \star * \star}$ & GCTCGTC & -39 \\
\hline B. lactucae ham $34^{\mathrm{f}}$ & -85 & CGATCGGAAG & 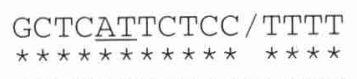 & САСТСТC & -54 \\
\hline B. lactucae $h s p 70^{\mathrm{f}}$ & -78 & TCTCAAGTTT & $\begin{array}{l}\text { GCTCACTTTGAAATTT } \\
\star \star \star \star \star \star * \star * \star * \star * \star * \star *\end{array}$ & TCCATCT & -46 \\
\hline
\end{tabular}

Numbers refer to the position of the first and last nt of the depicted sequence relative to the ATG start codon of the respective gene. Nucleotides marked with an asterisk match with the consensus sequence GCTCATTYYNCA(A/T)TTT. In the $P$. infestans act $A$ sequence, the $P$. parasitica par $A l$ sequence and the B. lactucae ham 34 sequence, a one-nt gap, indicated by a slash $(/)$, is introduced in the conserved motif to obtain optimal alignment. The position of the transcription start point is underlined.

Pieterse et al. (1994b). The nt sequence shown is present in the promoter region of the P. infestans ipiB2 and ipiB3 gene. The $n t$ sequence at positions -62 to -94 relative to the ATG start codon of the ipiBI gene was not determined. The transcription start point has not been determined.

Pieterse et al. (1994b). The nt sequence at position -8 to -40 relative to the ATG start codon of ipiOI and ipiO2 is nearly identical. Only at position -34 , the $\mathrm{A}$ in ipiO1 is a $\mathrm{G}$ in $\mathrm{ipiO} 2$.

'Pieterse et al. (1991).

Pieterse et al. (1993b).

For references see Pieterse et al. (1994b).

* In the $a c t B$ promoter region five transcription start points have been found which are all located more upstream of the depicted sequence between positions -120 and -164 relative to the ATG start codon.

"Kamoun et al. (1993a).

Sacks et al. (1995). Sequence is derived from cDNA clones.

CaMV, respectively) are inactive in $P$. infestans, in $P$. sojae, and in the oomycetous water mold Achlya ambisexualis (Judelson et al. 1992). On the other hand, expression of marker genes regulated by oomycete gene promoters is not detectable in higher fungi such as Aspergillus nidulans, Saccharomyces cerevisiae, Neurospora crassa, and Ustilago maydis (Judelson et al. 1992; Pieterse et al.1995). Apparently, the regulatory mechanisms involved in gene activation are not conserved between fungi and chromista. One remarkable feature found in promoters of several Phytophthora genes and two Bremia lactucae genes is a conserved DNA sequence motif surrounding the transcription start site (Table 1). This motif is not found in gene promoters of higher fungi, plants, or animals, but whether or not it is important for regulation or initiation of transcription is unknown.

\section{Elicitors Produced by Phytophthora Species}

Elicitors constitute a large class of chemically diverse molecules derived from plant pathogens which stimulate defense responses in intact plants or cultured plant cells. Several different types of elicitor molecules produced by various Phytophthora spp. have been identified. For example, the 
root and stem rot pathogen $P$. sojae produces at least three distinct elicitor molecules. One is a cell wall-bound oligoglucoside that induces phytoalexin synthesis in cotyledons of the host of $P$. sojae, soybean. Specific binding of the oligoglucoside elicitor to soybean plasma membranes has been demonstrated, suggesting that elicitor perception and signal transduction involves a transmembrane receptor-mediated process (Ebel and Cosio 1994; Chap. 5, Vol. V, Part A).

The second elicitor identified in P. sojae is an extracellular glycoprotein that induces defense responses, oxidative burst, and ion fluxes in the nonhost parsley (Nürnberger et al. 1994). Characterization of corresponding cDNA clones showed that the entire gene encodes a $57-\mathrm{kDa}$ precursor protein. After cleavage of the signal peptide the $\mathrm{N}$-terminal part of the protein is removed, most likely by proteolytic processing, generating the 43$\mathrm{kDa}$ mature elicitor that is present in culture filtrates. Elicitor activity was found to reside in the protein moiety of the glycoprotein (Sacks et al. 1995). Protease treatment released an oligopeptide consisting of 13 amino acids that stimulated the same responses as the intact elicitor, whereas other fragments of the protein were devoid of elicitor activity (Nürnberger et al. 1994). Also for this elicitor, specific binding to plasma membranes has been demonstrated.

The third elicitor is a $10-\mathrm{kDa}$ protein which belongs to a family of proteins collectively termed elicitins. Elicitins are produced by many Phytophthora species (Pernollet 1993). They are synthesized as preproteins with a signal peptide which is removed cotranslationally before secretion in the culture medium. The 98 -amino-acid mature proteins are not glycosylated. Elicitins induce a vigorous defense response in tobacco, resulting in resistance to the black shank agent, Phytophthora parasitica. P. parasitica isolates which are nonpathogenic in tobacco produce the elicitin called parasiticein, whereas most isolates pathogenic on tobacco do not produce elicitins (Ricci et al. 1992). Therefore, these proteins have been proposed to act as avirulence factors in the $P$. parasiticatobacco interaction. It has been demonstrated that parasiticein is responsible for activation of both localized and distal hypersensitive responses in tobacco (Kamoun et al. 1993b). Recent studies on the three-dimensional structure of the $P$. capsici elicitin capsicein revealed that capsicein has structural features typical for phospholipase A2. Purified capsicein was found to have phosholipase A2 activity, suggesting that the defense signaling pathway triggered by capsicein involves the jasmonic acid route, fostered by the release of linolenic acid (J.-C. Pernollet, pers. comm.).

Neither the 42-kDa glycoprotein nor the 10 $\mathrm{kDa} P$. sojae elicitin, which is an active elicitor on tobacco, induces defense responses in soybean, the natural host of $P$. sojae. They seem to serve as signals of nonself-recognition by nonhost plants. However, the biological function of these two elicitors in $P$. sojae remains unknown. The gene encoding the $42-\mathrm{kDa}$ elicitor is part of a gene family. The presence of this gene family appears to be a property common to Phytophthora species, but not all species produce a protein that cross-reacts with antiserum raised against the elicitor (Sacks et al. 1995). Also elicitins are coded by members of gene families and elicitin genes are conserved in many tested Phytophthora species. Even some $P$. parasitica isolates that do not produce elicitins, and are virulent on tobacco, have elicitin-coding sequences in their genomes (Kamoun et al. 1993a).

In addition to the three different types of elicitor molecules described above, $P$. sojae most likely produces race-specific elicitors. $P$. sojae interacts with soybean in a gene-for-gene manner. Several dominant avirulence genes, which may have a function in the synthesis of race-specific elicitors, have been characterized genetically (Whisson et al. 1994; B.M. Tyler, pers. comm.). However, the biochemical nature of race-specific elicitors produced by $P$. sojae or any other Phytophthora species is so far unknown. In view of the observation that from the three $P$. sojae elicitors mentioned above, only the oligoglucoside elicitor is able to induce defense responses in soybean, it might well be that modifications of oligoglucosides determine compatibility or incompatibility, but as yet there are no indications pointing in that direction.

A completely different class of elicitor molecules found in all species of Phytophthora are the polyunsaturated fatty acids, eicosapentaenoic acid (EPA) and arachidonic acid (AA). EPA and AA are active elicitors of defense responses in potato. Incompatible as well as compatible races of $P$. infestans release AA while invading potato leaves (Ricker and Bostock 1992). This finding is in agreement with the cytological studies of Freytag et al. (1994), who observed hypersensitive reacting mesophyll cells not only in incompatible but also compatible interactions and suggested that the difference between compatibility and incompatibility 
due to comparatively small quantitative difference in the number of mesophyll cells that respond hypersensitively. How these quantitative differences are determined and what the function of putative race-specific elicitors or suppressors is in this process is unclear.

\section{Pathogenicity of Phytophthora infestans}

P. infestans is hemibiotrophic, which means that in nature the pathogen does not exist in an independent mycelial form. Growth and reproduction require colonization of the host. In initial stages of the interaction encysted zoospores germinate on the leaf surface and form appressoria. When an appropriate artificial surface is provided, germination and appressorium formation proceed in water in the absence of the host. Apparently, the zoospores carry sufficient food reserves for the initial stages, but once these reserves are exhausted, the host must be penetrated. Hence, the pathogen must possess the machinery required for growth and development in the host environment.

Pathogenesis in plants is often associated with the production of extracellular hydrolytic enzymes by the pathogen. These proteins may facilitate penetration of the pathogen and colonization of the host by damaging host tissue. Fungi typically exhibit absorptive nutrition (Hohl 1991a). Therefore, hydrolytic extracellular enzymes are important prerequisites for growth on complex, high-molecular-weight substrates. The first barrier for the pathogen, the plant cuticle, can be degraded by cutinase. For some pathogens cutinase seems to be important for penetration (Chap. 3, Vol. V, Part A; Chap. 3, this Vol.), but other plant pathogens can still penetrate when the cutinase gene is inactivated (Stuhl and Schäfer 1992). To our knowledge, the involvement of cutinase in the potato- $P$. infestans interaction has never been studied. Since $P$. infestans forms an appressorium, it might be able to penetrate host cells directly with physical force in a fashion similar to $M$. grisea (Chap. 3, Vol. V, Part A; Chap. 3, this Vol.) The biotrophic nature of $P$. infestans suggests that the cell wall-degrading enzyme system of the pathogen is under tight control. Cell walls may be degraded to some extent to facilitate the fungal hyphae to grow through the tissue, but the host cells should not be destroyed. During growth of
$P$. infestans in vitro, several hydrolytic enzymes are secreted in the culture medium (Moreau and Seibles 1985). Endocellulases, $1,3-\beta$-glucanases, $\beta$ glucosidases, pectin-esterases, polygalacturonases, and galactanases of $P$. infestans have all been isolated (Friend 1991), but individually none of these shows massive cell wall-degrading activity. Infection of tubers with $P$. infestans causes dry rot, suggesting that cell wall decomposition does not contribute substantially to nutrition of the pathogen (Hohl 1991a). Probably extracellular hydrolytic enzymes do not play a decisive role in pathogenesis of $P$. infestans.

Phytotoxins are a diverse group of lowmolecular-weight secondary metabolites which have been shown to be pathogenicity factors of several plant pathogens. Phytotoxic metabolites have been isolated from culture fluids of $P$. infestans (Möllers et al. 1992), but their involvement in disease development still remains to be demonstrated.

\section{A. Differential Gene Expression During Pathogenesis}

It is clear that the importance of the few potential pathogenicity factors studied so far in the potato$P$. infestans interaction has not been established convincingly; further, little is known about the molecular basis underlying pathogenicity of $P$. infestans. The specificity of $P$. infestans for solanaceous hosts cannot be explained simply by the action of general pathogenicity factors described above. This specificity implies a mechanism for recognition which involves the exchange of signals between host and pathogen. Successful colonization probably requires the expression of particular pathogenicity genes, i.e., genes of the pathogen which are essential for the establishment and maintenance of a compatible interaction. It is possible that, as in other symbiotic or pathogenic plant-microbe interactions, signal molecules originating from the host, or environmental stimuli present in the host, induce the expression of genes in the micro-organism which are necessary for the establishment of a successful interaction (Peters and Verma 1990). Hence, one approach to gain more insight into the molecular processes involved in pathogenesis of $P$. infestans is based on the characterization of genes of the pathogen whose expression is induced during a compatible interaction with the host plant. Once the gene 
products of these so-called in planta-induced genes are characterized, their role in pathogenicity can be studied.

A powerful technique to select genes induced in planta involves differential screening of a genomic library of the pathogen with probes derived from mRNA isolated from infected plant tissues and mRNA isolated from the in vitro-cultured pathogen. The selection is nonbiased, enabling the identification of genes whose role in pathogenicity cannot be predicted by other methods. Such a differential screening procedure does not exclusively select pathogenicity genes. Also genes induced in planta which are not directly involved in pathogenicity may be selected, e.g., fungal genes encoding products involved in adaptations to a change in nutrient environment encountered upon invasion of the host. Nevertheless, by identifying this type of differentially expressed genes, one can acquire a better understanding of the cellular processes which change during pathogenesis.

By means of differential screening of a genomic library of $P$. infestans, nine distinct genes have been isolated (Pieterse et al. 1993a; Fig. 4; Table 2). A detailed characterization of two of these genes, ubi3R and calA, showed that they encode the ubiquitous proteins ubiquitin and calmodulin, respectively. Ubi3R and calA are expressed during growth of $P$. infestans in vitro but the expression levels increase and are continuously fivefold higher during pathogenesis on potato (Pieterse et al. 1991, 1993b). Ubiquitin and calmodulin are highly conserved proteins in all eukaryotic organisms, indicating that they play important roles in basic cellular processes. This is the first time that increased expression of genes encoding ubiquitin and calmodulin has been found in association with fungal pathogenicity. Although these proteins cannot be considered as primary pathogenicity factors, they may have important functions in cellular processes which change during pathogenesis.

Ubiquitin has been shown to play a key role in selective degradation of abnormal proteins which arise during stress, in maintenance of chromatin structure, in modification of cell surface receptors, and in regulation of gene expression (Monia et al. 1990), all processes which are likely to proceed during pathogenesis. Failure to regulate these processes correctly, due to insufficient ubiquitin concentrations, may counteract the pathogenic process. Calmodulin is one of the major intracellular $\mathrm{Ca}^{2+}$ receptors and is responsible for mediating

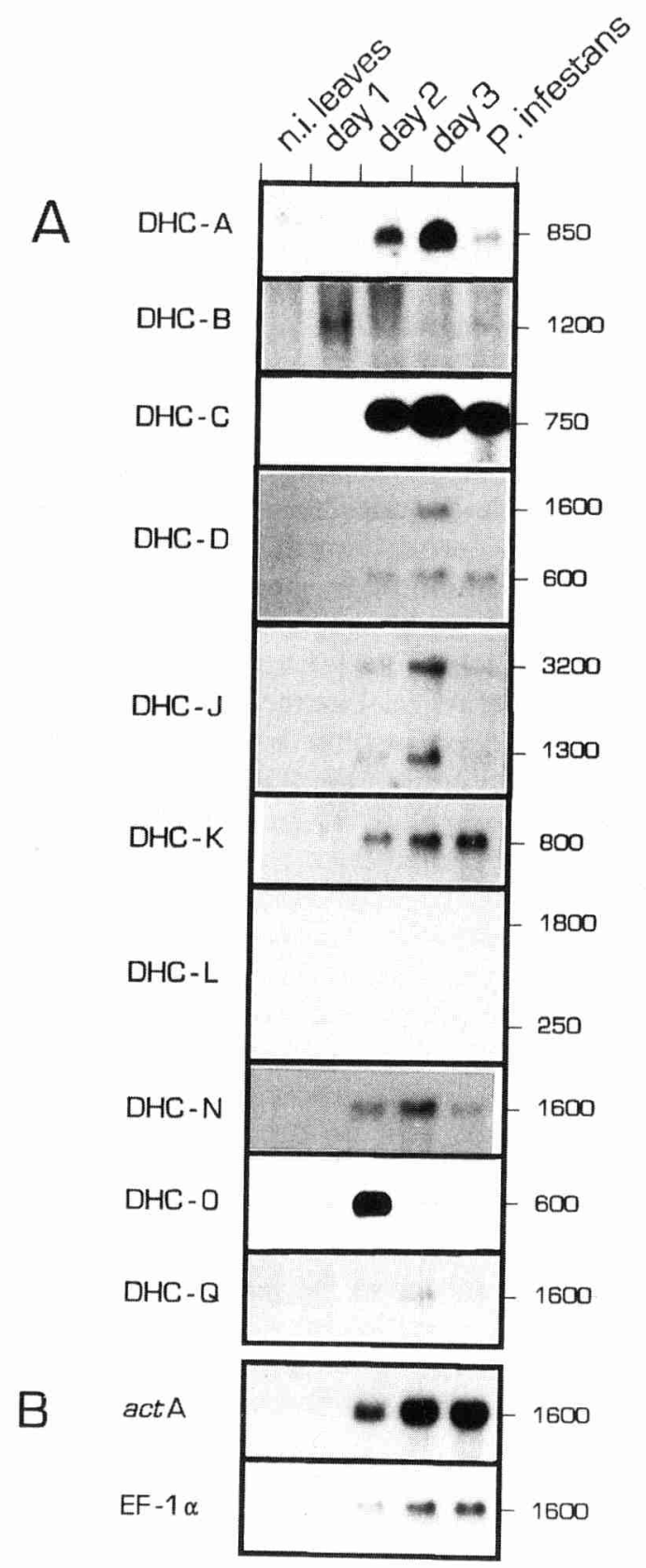

Fig. 4. Exprssion of Phytophthora infestans genes during colonization of potato leaves. Autoradiographs of northern blots containing total RNA isolated from non-inoculated potato leaves (n.i. leaves), from leaves colonized by $P$. infestans at different time points after inoculation (day 1, day 2 , and day 3 ), and from $P$. infestans mycelium grown in vitro $(P$. infestans $)$. The blots were hybridized with $(\mathbf{A})$ probes derived from DNA fragments located on various differentially hybridizing clones $(D H C)$ selected from a $P$. infestans genomic library by differential screening and $(\mathbf{B})$ as a control, probes derived from constitutively expressed genes. The DNA fragments from the $D H C$ clones represent $P$. infestans ipi and pig genes as shown in Table 2. (Pieterse et al. 1993a) 
Table 2. Normalized mRNA levels of Phytophthora infestans ipi and pig genes during colonization of potato leaves. (Pieterse et al. 1993a)

\begin{tabular}{|c|c|c|c|c|c|c|c|}
\hline \multirow[t]{2}{*}{ Gene } & \multirow[t]{2}{*}{ Location } & \multirow{2}{*}{$\begin{array}{l}\text { Transcript } \\
\text { length (nt) }\end{array}$} & \multicolumn{5}{|c|}{ Normalized mRNA levels ${ }^{\mathrm{a}}$} \\
\hline & & & n.i. ${ }^{b}$ & Day $1^{\mathrm{b}}$ & Day $2^{b}$ & Day $3^{b}$ & P. infestans ${ }^{\mathrm{b}}$ \\
\hline$i p i A(u b i 3 R)$ & DHC-A & 850 & - & - & 10 & 10 & 1 \\
\hline ipiB & DHC-B & 1200 & - & $>100$ & 1 & 1 & 1 \\
\hline ipiC (calA) & DHC-C & 750 & - & - & 5 & 4 & 1 \\
\hline ipiD & DHC-D & 1600 & - & - & 10 & 10 & 1 \\
\hline pigD & DHC-D & 600 & - & - & 1 & 1 & 1 \\
\hline ipiJl & DHC-J & 3200 & - & - & 10 & 8 & 1 \\
\hline ipiJ2 & DHC-J & 1300 & - & - & 9 & 9 & 1 \\
\hline $\operatorname{pig} K$ & DHC-K & 800 & - & - & 1 & 1 & 1 \\
\hline \multirow[t]{2}{*}{$\operatorname{pig} L$} & DHC-L & 1800 & - & - & - & 1 & 1 \\
\hline & & 250 & \# & \# & - & - & - \\
\hline ipiN & DHC-N & 1600 & - & - & 5 & 5 & 1 \\
\hline ipiO & $\mathrm{DHC}-\mathrm{O}$ & 600 & - & $35^{\mathrm{c}}$ & $35^{\mathrm{c}}$ & $1^{\mathrm{c}}$ & - \\
\hline ipiQ & DHC-Q & 1600 & - & - & 5 & 9 & 1 \\
\hline
\end{tabular}

-. No mRNA detectable; \#, mRNA of plant origin.

" mRNA levels were measured by densitometric scanning of autoradiographs and normalized to actual fungal RNA levels using the signals obtained with probes derived from the constitutively expressed marker genes act $A$ and EF-1 $\alpha$. Densitometric scanning of the act $A$ and EF- $1 \alpha$ signals shown in Fig. 4 revealed that interaction RNAs isolated at day 1 , day 2 , and day 3 postinoculation contained 5, 25, and 70\% fungal RNA, respectively. All values obtained by densitometric scanning of the hybridization signals shown in Fig. 4 were adjusted to the equivalent of $100 \%$ fungal RNA and subsequently compared to those values obtained with RNA isolated from $P$. infestans grown in vitro. Numbers indicate the increase in actual mRNA levels in comparison to the mRNA levels in $P$. infestans grown in vitro which is set at 1.

bee legend Fig. 4.

In P. infestans grown in vitro, ipiO mRNA is not detectable. Therefore, signals obtained in lanes containing interaction RNA are compared with each other.

cellular responses to $\mathrm{Ca}^{2+}$ fluxes which are generated by a variety of processes. It has been shown in several organisms that, via $\mathrm{Ca}^{2+}$-calmodulin complexes, calmodulin is involved in the transduction of signals from extracellular stimuli into intracellular events (Roberts et al. 1986). Therefore, it is tempting to speculate that calmodulin is involved in the communication between plant and pathogen. Unfortunately, the involvement of both ubiquitin and calmodulin in various basic cellular processes makes it difficult to study the significance of increased $u b i 3 R$ and calA gene expression during pathogenesis. Manipulating the synthesis or activity of ubiquitin or calmodulin will influence all other cellular processes which are dependent on these proteins. As a consequence, a straightforward interpretation of such studies will be impossible.

Two other genes, ipiB and ipiO, show a transient expression pattern, with the higher expression levels in early stages of infection (Fig. 4; Table 2; Pieterse et al. 1994a). They both belong to small gene clusters encoding novel proteins with yet unknown functions. IpiB belongs to a gene family of which three highly homologous members, ipiB1, ipiB2, and ipiB3, are closely linked on the genome. The primary structure of the IPI-B proteins consists of an amino terminal signal peptide for secretion followed by a highly repetitive, glycine-rich domain which comprises most of the protein (Pieterse et al. 1994b). The IPI-B proteins share these characteristics with plant glycine-rich proteins, some of which have been shown to be associated with the cell wall (Showalter 1993). In germinating cysts and during early stages of the interaction, ipiB mRNA accumulates to very high levels. The possible association of the $i p i B$ gene products with the cell wall suggests that they are involved in the development of infection structures like appressoria or primary hyphae. In more advanced stages of the infection process and during growth of $P$. infestans in vitro, ipi $B$ mRNA is hardly detectable, indicating that for mycelial growth, high levels of IPI-B proteins are not required. Immunological studies with antisera raised against the IPI-B proteins could provide more insight into this matter.

$P$. infestans has two almost identical ipiO genes which are located within a 5 -kb genomic region (Pieterse et al. 1994b). Like the IPI-B proteins, the IPI-O proteins contain an amino terminal signal peptide, suggesting that the proteins are 
secreted. The mature proteins have a putative Nglycosylation site and contain the tripeptide sequence Arg-Gly-Asp (RGD), a conserved motif found in several mammalian extracellular matrix proteins in which it functions as a cell-attachment sequence (D'Souza et al. 1991). Accumulation of ipiO mRNA follows a transient pattern and coincides with colonization of the host cells. Once colonization of host tissue is completed, ipiO mRNA level decreases dramatically to low or undetectable levels. Also during growth of the pathogen in vitro, ipiO mRNA cannot be detected, indicating that IPI-O proteins are synthesized exclusively during the biotrophic phase of the pathogenic interaction. Based on the assumption that the IPI-O proteins are extracellular, we speculate that they might have a function in the extracellular matrix where components produced by the pathogen interact directly with plant cells. In view of this, the RGD sequence motif in the IPI-O proteins might play a role in the pathogenicity of $P$. infestans. We hypothesize that through the RGD sequence, IPI$\mathrm{O}$ can be involved either in attachment of $P$. infestans to the plant cells or disturbance of the normal RGD-mediated signaling, which supposedly occurs in healthy plant tissues.

The RGD tripeptide motif was first identified in several mammalian adhesion proteins, such as fibronectin, vitronectin, and the Von Willebrand coagulation factor, and it was demonstrated to be a cell attachment sequence crucial for cellsubstratum adhesion (D'Souza et al. 1991). The RGD tripeptide is responsible for the interaction of extracellular adhesion proteins with cell surface receptors, the so-called integrins (Hynes 1992). These specific ligand-receptor interactions mediate adhesion of cells to the extracellular matrix and play an essential role in intercellular communication and development of mammalian cells. Also in lower eukaryotes, cell adhesion molecules with a functional RGD-tripeptide are found. An example is discoidin I, which plays a role in the aggregation of the slime mold Dictyostelium discoideum (Gabius et al. 1985). In addition, pathogenicity factors of some bacteria pathogenic for humans contain a functional RGD-tripeptide which interacts with integrins on the surface of host cells, thereby mediating uptake into the host cells (Finlay 1990). Furthermore, the RGD-containing VP1 protein of the foot-and-mouth disease virus appears to interact with integrin-like molecules on the surface of the host cells in an RGD-dependent manner, suggesting that also viruses utilize RGD-dependent interactions for host invasion (Fox et al. 1989).
If the IPI-O proteins truly function as adhesion molecules in a RGD-dependent fashion and attach to plant cells, then receptor-ligand interactions, i.e., plasma membrane-cell wall interactions, involving RGD-containing proteins and integrinlike molecules, should occur in plants. Although the walled cells of plants differ from animal cells, there are several observations which suggest that RGD-dependent adhesion processes similar to those found in mammals occur at the surface of the plasma membrane of plant cells. First, proteins immunologically related to human vitronectin and its integrin receptor have been found in plants and green algae (Schindler et al. 1989; Wagner et al. 1992; Wang et al. 1994). Secondly, Schindler et al. (1989) showed that the RGD-containing hexapeptide Gly-Arg-Gly-Asp-Ser-Pro (GRGDSP), specifically disrupted cell membrane-cell wall attachment in soybean suspension cells whereas the control hexapeptides Gly-Arg-Gly-Glu-SerPro (GRGESP) and Gly-Asp-Gly-Arg-Ser-Pro (GDGRSP) did not. Thirdly, studies of Zhu et al. (1993) demonstrated that protoplasts prepared from tobacco cells which are adapted to grow in high salt concentrations adhere tightly to each other and that this typical tight adhesion is specifically blocked by the GRGDSP hexapeptide. They also found that vitronectin-like proteins are enriched in these high salt-adapted cells. Finally, Sanders et al. (1991) found that vitronectin-like proteins were enriched on the surfaces of cells lining the stylar duct through which pollen tubes grow to deliver the pollen nuclei to the ovule.

Using plasmolysis techniques, Nozue et al. (1979) demonstrated tight adherence of the potato plasmalemma to infecting hyphae of $P$. infestans from the earliest time of penetration. In addition, Hohl (1991b) and Gross et al. (1993) demonstrated adhesion of hyphae of Phytophthora sojae and $P$. infestans to protoplasts of soybean and parsley, respectively. Based on these findings it can be postulated that hyphae produce extracellular adhesion proteins which facilitate attachment to host cells. When these adhesion molecules function via RGD-dependent ligand-receptor interactions, it is also possible that they compete with RGDcontaining proteins produced by the host, thereby disturbing the regular RGD-mediated ligandreceptor interactions and creating beneficial conditions for colonization of the host tissue. Adhesion molecules may also reside in the extrahaustorial matrix, a very thin layer of unknown material between the haustorium and the plasmalemma of the host cell. The extrahaustorial matrix 
is thought to be of fungal origin and may have a function in recognition or in nutrient uptake, either through suppressing a host resistance response, or by activating physiological changes in the host which are beneficial for the maintenance of a compatible interaction between host and pathogen (Coffey and Gees 1991). Whether the $P$. infestans IPI-O proteins indeed have cell adhesion properties and operate as hypothesized above, and whether RGD-mediated adhesion interactions in general play a role in pathogenesis, are interesting questions to address in the future.

\section{B. Differential Gene Expression During Starvation}

In $P$. infestans expression of the ipiB and ipiO genes is specifically induced in planta, whereas during growth in a rich culture medium expression is not detectable. However, during growth in vitro, the expression of both the $i p i B$ and $i p i O$ genes can be activated by nutrient deprivation (Pieterse et al. 1994a). Interestingly, transcriptional activation by nutrient deprivation has been reported for two other genes of plant pathogens, i.e., the avirulence gene avr9 of Cladosporium fulvum, which is specifically expressed when the nitrogen source in the growth medium is limited (van den Ackerveken et al. 1994; Chap. 1, this Vol.) and the putative pathogenicity gene MPGl of Magnaporthe grisea, whose expression can be induced in vitro by glucose deprivation (Talbot et al. 1993; Chap. 3, this Vol.). It is tempting to speculate that upon infection of a host plant, nutrient deprivation or changes in nutrient conditions trigger the expression of a set of pathogenicity genes whose gene products facilitate establishment of a beneficial environment for the pathogen. If transcriptional activation of pathogenicity genes by nutrient deprivation is a general phenomenon, selecting for genes which are specifically expressed in starvation-stressed cells could be a useful approach for the isolation of putative pathogenicity genes of a wide range of plant pathogens.

\section{Perspectives and Conclusions}

To establish effective control strategies for potato late blight, increased investigation and education are needed. The population displacement in Europe in the early 1980s, and the acquired ability of $P$. infestans to reproduce sexually and to overwinter in soil, independent of living host tissue, have dramatically changed the behavior of the pathogen population. Therefore, one must realize that a continuous evaluation of the pathogen population is required. For practical disease management, the danger of the emergence of new virulence factors, fungicide-resistant isolates, and more aggressive isolates should not be underestimated.

The search for alternative methods of disease control should be intensified. This certainly requires more knowledge about pathogenicity factors, elicitors, and other compounds produced by the pathogen, and about defense responses elicited in the host. The signaling processes between plant and pathogen have to be unraveled so that vital links in the signaling pathways, which lead to the destruction of the host, are recognized. Such knowledge should be instrumental in the development of environmentally friendly control strategies which are based on interference in the signaling pathways, either through genetic modification of the host or by application of very specifically targeted inhibitory compounds.

\section{Note added in proof}

This review was written in August 1994. Publications that have appeared from that time on are not cited. Recently, an excellent review by Howard S. Judelson covering recent advances in the genetics of oomycete plant pathogens was published in the journal, Molecular Plant-Microbe Interactions (1996, volume 9, pp. 443-449). For updated literature on population genetics, we refer to the article, The Population Genetics of Phytophthora, by Stephen B. Goodwin in Phytopathology. (1997, volume 87, pp. 462-473)

Acknowledgments. We thank our colleagues working with Phytophthora for allowing us to cite their unpublished results, and Carlos Alfonso, Anke de Jong, and Pieter van West for their critical comments on the manuscript.

\section{References}

Alani E, Cao L, Kleckner N (1987) A method for gene disruption that allows repeated use of URA3 selection in construction of multiple disrupted yeast strains. Genetics 116:541-545 
Alexopoulos CJ, Mims CW, Blackwell M (1996) Introductory mycology. John Wiley, New York

Bailey AM, Mena GL, Herrera-Estrella L (1991) Genetic transformation of the plant pathogens Phytophthora capsici and Phytophthora parasitica. Nucleic Acids Res 19:4273-4278

Bailey AM, Mena GL, Herrera-Estrella L (1993) Transformation of four pathogenic Phytophthora spp. by microprojectile bombardment on intact mycelia. Curr Genet 23:42-46

Black W, Mastenbroek C, Mills WR, Peterson LC (1953) A proposal for an international momenclature of races of Phytophthora infestans and of genes controlling immunity in Solanum demissum derivatives. Euphytica 2:173-179

Bourke PMA (1964) Emergence of potato blight, 1843-46. Nature 203:805-808

Charlesworth B (1989) The evolution of sex and recombination. Trends Ecol Evol 9:264-267

Coffey MD, Gees R (1991) The cytology of development. In: Ingram DS, Williams PH (eds) Phytophthora infestans, the cause of late blight of potato. Advances in plant pathology 7. Academic Press, London, pp 3151

Crute I (1992) From breeding to cloning (and back again?): a case study with lettuce downy mildew. Annu Rev Phytopathol 30:485-506

Davidse LC, Looijen D, Turkensteen LJ, Van der Wal D (1981) Occurrence of metalaxyl-resistant strains of Phytophthora infestans in The Netherlands. Eur Plant Prot Organ Bull 15:403-409

de Bary A (1876) Researches into the nature of the potato fungus Phytophthora infestans. J R Agric Soc Engl $12: 239-269$

Doke N, Miura Y, Sanchez LM, Yoshioka H, Kawakita K (1993) Signal transduction and hypersensitive reaction in Phytophthora-Solanaceae plant pathosystem: superoxide generating reaction. In: Kohmoto K, Yoder OC (eds) Host-specific toxin: biosynthesis, receptor and molecular biology. Tottori University, Tottori, Japan, pp 153-167

Drenth A, Goodwin SB, Fry WE, Davidse LC (1993a) Genotypic diversity of Phytophthora infestans in The Netherlands revealed by DNA polymorphisms. Phytopathology 83:1087-1092

Drenth A, Turkensteen LJ, Govers F (1993b) The occurrence of the A2 mating type of Phytophthora infestans in The Netherlands: signifiance and consequences. Neth J Plant Pathol 99 (Suppl 3):57-67

Drenth A, Tas ICQ, Govers F (1994) DNA fingerprinting uncovers a new sexually reproducing population of Phytophthora infestans in The Netherlands. Eur J Plant Pathol 100:97-107

Drenth A, Janssen EM, Govers F (1995) Formation and survival of oospores of Phytophthora infestans under natural conditions. Plant Pathol 44:86-94

D'Souza SE, Ginsberg MH, Plow EF (1991) Arginyl-glycyl-aspartic acid (RGD): a cell adhesion motif. TIBS 16:246-250

Ebel J, Cosio EG (1994) Elicitors of plant defense responses. Int Rev Cytol 148:1-36

Finlay BB (1990) Cell adhesion and invasion mechanisms in microbial pathogenesis. Curr Opin Cell Biol 2:815820

Fox G, Parry NR, Varnett PV, McGinn B, Rowlands DJ, Brown F (1989) The cell attachment site on foot-andmouth disease virus includes the amino acid sequence
RGD (arginine-glycine-aspartic acid). J Gen Virol 70: 625-637

Freytag S, Arabatzis N. Hahlbrock K, Schmelzer E (1994) Reversible cytoplasmic rearrangements precede wall apposition, hypersensitive cell death and defense-related gene activation in potato/Phytophthora infestans interactions. Planta 194:123-135

Friend J (1991) The biochemistry and cell biology of interaction. In: Ingram DS, Williams PH (eds) Phytophthora infestans, the cause of late blight of potato. Advances in plant pathology 7. Academic Press, London, pp 85 129

Fry WE, Goodwin SB, Dyer AT, Matuszak JM, Drenth A. Tooley PW, Sujkowski LS, Koh YJ, Cohen BA. Spielman LJ, Deahl KL, Inglis DA, Sandlan KP (1993) Historical and recent migrations of Phytophthora infestans: chronology, pathways and implications. Plant Dis 77 : 653-661

Gabius H-J, Springer WR, Barondes SH (1985) Receptor for the cell binding site of Discoidin I. Cell 42:449 456

Goodwin SB, Drenth A, Fry WE (1992a) Cloning and genetic analyses of two highly polymorphic, moderately repetitive nuclear DNAs from Phytophthora infestans. Curr Genet 22:107-115

Goodwin SB, Spielman LJ, Matuszak JM, Bergeron SN, Fry WE (1992b) Clonal diversity and genetic differentiation among Phytophthora infestans populations in northern Mexico. Phytopathology 82:955-961

Goodwin SB, Cohen BA, Deahl KL, Fry WE (1994) Migration from northern Mexico as the probable cause of recent genetic changes in populations of Phytophthora infestans in the United States and Canada. Phytopathology 84:553-558

Gross P. Julius C, Schmelzer E. Hahlbrock K (1993) Translocation of cytoplasm and nucleus to fungal penetration sites is associated with depolymerization of microtubules and defence gene activation in infected, cultured parsley cells. EMBO J 12:1735-1744

Hawksworth DL, Kirk PM, Sutton BC, Pegler DN (eds) (1995) Ainsworth and Bisby's Dictionary of the Fungi. International Mycological Institute. CAB International, Oxon UK

Hohl HR (1991a) Nutrition. In: Ingram DS, Williams PH (eds) Phytophthora infestans, the cause of the late blight of potato. Advances in plant pathology 7. Academic Press, London, pp 53-83

Hohl HR (1991b) Host-pathogen interactions in Phytophthora. In: Lucas JA, Shattock RC, Shaw DS, Cooke LR (eds) Phytophthora. Cambridge University Press, Cambridge, pp 295-311

Hohl HR, Iselin K (1984) Strains of Phytophthora infestans with A2 mating type behaviour. Trans $\mathrm{Br}$ Mycol Soc 83:529-530

Holub E, Crute I, Brose E, Beynon J (1993) Identification and mapping of loci in Arabidopsis for resistance to downy mildew and white blister. In: Davis KR. Hammerschmidt R (eds) Arabidopsis thaliana as a model for plant-pathogen interactions. APS Press, St Paul, pp 2135

Holub EB, Beynon JL, Crute IR (1994) Phenotypic and genotypic characterization of interactions between isolates of Peronospora parasitica and accessions of Arabidopsis thaliana. Mol Plant-Microbe Interact 7:223-239

Hynes RO (1992) Integrins: versatility, modulation, and signalling in cell adhesion. Cell 69:11-25

Ingram DS, Williams PH (eds) (1991) Advances in plant 
pathology 7. Phytophthora infestans, the cause of late blight of potato. Academic Press, London

Judelson HS, Michelmore RW (1991) Transient expression of genes in the oomycete Phytophthora infestans using Bremia lactucae regulatory sequences. Curr Genet 19:453-459

Judelson HS. Tyler GM, Michelmore RW (1991) Transformation of the oomycete pathogen Phytophthora infestans. Mol Plant-Microbe Interact 4:602-607

Judelson HS, Tyler BM, Michelmore RW (1992) Regulatory sequences for expressing genes in oomycete fungi. Mol Gen Genet 234:138-146

Judelson HS, Dudler R, Pieterse CMJ, Unkles SE, Michelmore RW (1993) Expression and antisense inhibition of transgenes in Phytophthora infestans is modulated by choice of promotor and position effects. Gene 133:6369

Kamoun S, Klucher KM, Coffey MD, Tyler Bm (1993a) A gene encoding a host-specific elicitor protein of Phytophthora parasitica. Mol Plant-Microbe Interact 6:573581

Kamoun S, Young M, Glascock CB, Tyler BM (1993b) Extracellular protein elicitors from Phytophthora: hostspecificity and induction of resistance to bacterial and fungal phytopathogens. Mol Plant-Microbe Interact 6:15-25

Karlovsky P. Prell HH (1991) The TRP1 gene of Phytophthora parasitica encoding indole-3-glycerolphosphate synthase-N-(5'-phosphoribosyl) anthranilate isomerase: structure and evolutionary distance from homologous fungal genes. Gene 109:161-165

Kinghorn JR, Moon RP, Unkles SE, Duncan JM (1991) Gene structure and expression in Phytophthora infestans and the development of gene-mediated transformation. In: Lucas JA, Shattock RC, Shaw DS, Cooke LR (eds) Phytophthora. Cambridge University Press, Cambridge, pp 295-311

Marmeisse R, van den Ackerveken GFJM, Goosen T, de Wit PJGM, van den Broek HWJ (1993) Disruption of the avirulence gene avr9 in two races of the tomato pathogen Cladosporium fulvum causes virulence on tomato genotypes with the complementary resistance gene Cf9. Mol Plant-Microbe Interact 6:412-417

Mills WR, Niederhauser JS (1953) Observations on races of Phytophthora infestans in Mexico. Phytopathology 43:454-455

Möllers C, Zitzlsperger J, Wenzel G (1992) The effects of a toxin preparation from Phytophthora infestans on potato protoplasts and microspores. Physiol Mol Plant Pathol 41:427-435

Monia BP, Ecker DJ, Crooke ST (1990) New perspectives on the structure and function of ubiquitin. Bio/Technology 8:209-215

Moreau RA. Seibles TS (1985) Production of extracellular enzymes by germinating cysts of Phytophthora infestans. Can J Bot 63:1811-1816

Newhouse JR, Tooley PW, Smith OP, Fishel RA (1992) Characterization of double-stranded RNA in isolates of Phytophthora infestans from Mexico, The Netherlands, and Peru. Phytopathology 82:164-169

Niederhauser JS, Mills WR (1953) Resistance of Solanum species to Phytophthora infestans in Mexico. Phytopathology 43:456-457

Nozue M. Tomiyama K, Doke N (1979) Evidence for adherence of host plasmalemma to infecting hyphae of both compatible and incompatible races of Phytophthora infestans. Physiol Plant Pathol 15:111-115
Nürnberger T, Nennstiel D, Jabs T, Sacks WR, Hahlbrock K, Scheel D (1994) High affinity binding of a fungal oligopeptide elicitor to parsley plasma membranes triggers multiple defense responses. Cell 78:449-460

Patterson DJ, Sogin ML (1992) Eukaryote origins and protistan diversity. In: Hartman H, Matsuno K (eds) The origin and evolution of prokaryotic and eukaryotic cells. World Scientific, Singapore, pp 13-46

Pernollet J-C (1993) Structural and biological properties of elicitins, toxic proteins secreted by Phytophthora fungi, which induce the plant defence responses. Proc Symp on Plant growth and environment, Suvon, Korea, 16 Oct 1993, pp 45-71

Peters NK, Verma DPS (1990) Phenolic compounds as regulators of gene expression in plant-microbe interactions. Mol Plant-Microbe Interact 3:4-8

Pieterse CMJ, Risseeuw EP, Davidse LC (1991) An in planta-induced gene of Phytophthora infestans codes for ubiquitin. Plant Mol Biol 17:799-811

Pieterse CMJ, Riach MBR, Bleker T, van den BergVelthuis GCM, Govers F (1993a) Isolation of putative pathogenicity genes of the potato late blight fungus Phytophthora infestans by differential hybridization of a genomic library. Physiol Mol Plant Pathol 43:6979

Pieterse CMJ, Verbakel HM, Hoek Spaans J, Davidse LC, Govers F (1993b) Increased expression of the calmodulin gene of the late blight fungus Phytophthora infestans during pathogenesis on potato. Mol Plant-Microbe Interact 6:164-172

Pieterse CMJ, Derksen A-MCE, Folders J, Govers F (1994a) Expression of the Phytophthora infestans ipiB and ipiO genes in planta and in vitro. Mol Gen Genet 244:269-277

Pieterse CMJ, van West P, Verbakel HM, Brassé PWHM, van de Berg-Velthuis, GCM, Govers F (1994b) Structure and genomic organization of the ipiB and ipiO gene clusters of Phytophthora infestans. Gene 138:6777

Pieterse CMJ, van 't Klooster J, van den Berg-Velthuis GCM, Govers F (1995) NiaA, the structural nitrate reductase gene of Phytophthora infestans: isolation, characterization and expression analysis in Aspergillus nidulans. Curr Genet 27:359-366

Ricci P. Trentin T, Bonnet P, Venard P (1992) Differential production of parasiticein, an elicitor of Phytophthora parasitica. Plant Pathol 41:298-307

Ricker KE, Bostock RM (1992) Evidence for release of the arachidonic aicd and its metabolites from sporangia of Phytophthora infestans during infection of potato. Physiol Mol Plant Pathol 41:61-72

Roberts DM, Lukas TJ, Watterson DM (1986) Structure, function, and mechanism of action of calmodulin. CRC Crit Rev Plant Sci 4:311-339

Sacks W, Nürnberger T, Hahlbrock K, Scheel D (1995) Molecular characterization of nucleotide sequences encoding the extracellular glycoprotein elicitor from Phytophthora megasperma. Mol Gen Genet 246:45-55

Sanders LC, Wang C-S, Walling LL, Lord EM (1991) A homolog of the substrate adhesion molecule vitronectin occurs in four species of flowering plants. Plant Cell 3:629-635

Schindler M, Meiners S, Cheresh DA (1989) RGDdependent linkage between plant cell wall and plasma membrane: consequences for growth. J Cell Biol 108:1955-1965

Schlager G, Dickie MM (1971) Natural mutation rates in 
the house mouse. Estimates for five specific loci and dominant mutations. Mutat Res 11:89-96

Schöber B, Turkensteen LJ (1992) Recent and future developments in potato fungal pathology. Neth J Plant Pathol 98 (Suppl 2):73-83

Shaw DS (1983) The Peronosporales. A fungal geneticist's nightmare. In: Buczacki ST (eds) Oosporic plant pathogens a modern perspective. Academic Press, London, pp 85-121

Showalter AW (1993) Structure and function of plant cell wall proteins. Plant Cell 5:9-23

Spielman LJ, McMaster BJ, Fry WE (1989) Dominance and recessiveness at loci for virulence against potato and tomato in Phytophthora infestans. Theor Appl Genet 77:832-838

Spielman LJ, Sweigard JA, Shattock RC, Fry WE (1990) The genetics of Phytophthora infestans: segregation of allozyme markers in F2 and backcross progeny and the inheritance of virulence against potato resistance R2 and R4 in F1 progeny. Exp Mycol 14:57-69

Spielman LJ, Drenth A, Davidse LC, Sujkowski LS, Gu W, Tooley PW, Fry WE (1991). A second world-wide migration and population displacement of Phytophthora infestans? Plant Pathol 40:422-430

Stahl DJ, Schäfer W (1992) Cutinase is not required for fungal pathogenicity on pea. Plant Cell 4:621-629

Sujkowski LS, Goodwin SB, Dyer AT, Fry WE (1994) Increased genotypic diversity via migration and possible occurrence of sexual reproduction of Phytophthora infestans in Poland. Phytopathology 84:201-207

Sweigard JA, Chumley FG, Valent B (1992) Disruption of a Magnaporthe grisea cutinase gene. Mol Gen Genet 232:183-190

Talbot NJ, Ebbole DJ, Hamer JE (1993) Identification and characterization of MPG1, a gene involved in pathogenicity from the rice blast fungus Magnaporthe grisea. Plant Cell 5:1575-1590

Thompson JN, Burdon JJ (1992) Gene-for-gene coevolution between plants and parasites. Nature 360:121-125

Tomiyama K (1983) Research on the hypersensitive response. Annu Rev Phytopathol 21:1-12

Tooley PW, Fry WE, Villarreal Gonzalez MJ (1985) Isozyme characterization of sexual and asexual Phytophthora infestans populations. J Hered 76:431-435

Van den Ackerveken GFJM, Dunn RM, Cozijnsen AJ, Vossen JPHJ, van den Broek HWJ, de Wit PJGM (1994) Nitrogen limitation induces expression of the avirulence gene avr9 in Cladosporium fulvum. Mol Gen Genet 243:277-285

Wagner VT, Brian L, Quatrano RS (1992) Role of a vitronectin-like molecule in embryo adhesion of the brown alga Fucus. Proc Natl Acad Sci USA 89:3644-3648

Wang C-S, Walling LL, Gu YQ, Ware CF, Lord EM (1994) Two classes of proteins and mRNAs in Lilium longiflorum L. identified by human vitroectin probes. Plant Physiol 104:711-717

Whisson SC, Drenth A, Maclean DJ, Irwin JAG (1994) Evidence for outcrossing in Phytophthora sojae and linkage of a DNA marker to two avirulence genes. Curr Genet 27:77-82

Woodham-Smith C (1962) The Great Hunger. Harper \& Row, New York

Zhu J-K, SHi J, Singh U, Wyatt SE, Bressan RA, Hasegawa PM, Carpita NC (1993) Enrichment of vitronectinand fibronectin-like proteins in $\mathrm{NaCl}$-adapted plant cells and evidence for their involvement in plasma membrane-cell wall adhesion. Plant J 3:637-646 